Renata Alves da Silva Carvalho'

Victor Santana Santos"

Cláudia Moura de Melo"II

Ricardo Queiroz Gurgelı

Cristiane Costa da Cunha

Oliveirav $^{v}$

\section{Inequalities in health: living conditions and infant mortality in Northeastern Brazil}

\section{Desigualdades em Saúde: condições de vida e mortalidade infantil em região do nordeste do Brasil}

Programa de Pós-Graduação em Saúde e Ambiente. Universidade Tiradentes. Aracaju, SE, Brasil

Programa de Pós-Graduação em Ciências da Saúde. Universidade Federal de Sergipe. Aracaju, SE, Brasil

III Laboratório de Doenças Infecciosas e Parasitárias. Instituto de Tecnologia e Pesquisa. Universidade Tiradentes. Aracaju, SE, Brasil

Departamento de Medicina. Universidade Federal de Sergipe. Aracaju, SE, Brasil

Laboratório de Planejamento e Promoção da Saúde. Instituto de Tecnologia e

Pesquisa. Universidade Tiradentes. Aracaju, SE, Brasil

\section{Correspondence:}

Renata Alves da Silva Carvalho

Av. Sílvio Cabral Santana, 455 casa 89 Cond.

Guilhermino Resende

49000-239 Aracaju, SE, Brasil

E-mail: renata.luca.2013@gmail.com

Received: 2/23/2013

Approved: 8/2/2014

Article avaiable from: www.scielo.br/rsp

\begin{abstract}
OBJECTIVE: To analyze the variation of infant mortality as per condition of life in the urban setting.

METHODS: Ecological study performed with data regarding registered deaths of children under the age of one who resided in Aracaju, SE, Northeastern Brazil, from 2001 to 2010. Infant mortality inequalities were assessed based on the spatial distribution of the Living Conditions Index for each neighborhood, classified into four strata. The average mortality rates of 2001-2005 and 2006-2010 were compared using the Student's t-test.
\end{abstract}

RESULTS: Average infant mortality rates decreased from 25.3 during 2001-2005 to 17.7 deaths per 1,000 live births in 2006-2010. Despite the decrease in the rates in all the strata during that decade, inequality of infant mortality risks increased in neighborhoods with worse living conditions compared with that in areas with better living conditions.

CONCLUSIONS: Infant mortality rates in Aracaju showed a decline, but with important differences among neighborhoods. The assessment based on a living condition perspective can explain the differences in the risks of infant mortality rates in urban areas, highlighting health inequalities in infant mortality as a multidimensional issue.

DESCRIPTORS: Infant Mortality, trends. Social Conditions. Health Status Disparities. Health Inequalities. Social Inequity. Child Health. Ecological Studies. 


\section{RESUMO}

OBJETIVO: Analisar a variação da mortalidade infantil por condição de vida no meio urbano.

MÉTODOS: Estudo ecológico realizado com dados de óbitos registrados de menores de um ano, residentes em Aracaju, SE, Nordeste do Brasil, de 2001 a 2010. As desigualdades na mortalidade infantil foram avaliadas pela distribuição espacial do Índice de Condições de Vida estabelecido para os bairros, classificados em quatro estratos. Foram comparadas as taxas de mortalidade infantil médias de 2001 a 2005 e 2006 a 2010 pelo teste $t$ Student.

RESULTADOS: A taxa de mortalidade infantil média declinou de 25,3 de 2001 a 2005 para 17,7 óbitos/1.000 nascidos vivos, de 2006 a 2010. Apesar da queda nas taxas em todos os estratos na década, a desigualdade no risco de morte infantil aumentou nos bairros com piores condições de vida em relação àqueles de melhores condições.

CONCLUSÕES: A mortalidade infantil em Aracaju apresentou declínio, mas com importante assimetria entre os bairros. A averiguação sob a ótica das condições de vida pode justificar as diferenças no risco de óbito infantil no espaço urbano, destacando as desigualdades em saúde na mortalidade infantil como fenômeno multidimensional.

DESCRITORES: Mortalidade Infantil, tendências. Condições Sociais. Disparidades nos Níveis de Saúde. Desigualdades em Saúde. Iniquidade Social. Saúde da Criança. Estudos Ecológicos.

\section{INTRODUCTION}

Infant mortality rates aid in the assessment of the living conditions of a population. Infant mortality is commonly used to verify the level of life and health of a location due to the fact of it being sensitive to improvements in the access to health care and quality of life. ${ }^{22}$ The condition of infant health, considered as being a classic indicator of public health, is associated with, among other factors, access to health services, sanitation, education level of the mother, housing, and nutrition. Reducing the mortality rate in children under the age of five is the fourth millennium goal of the United Nations Development Program (UNDP). Brazil reduced this rate by $5.2 \%$ from 1990 to $2008,{ }^{21}$ being one of the countries that have achieved the goal. According to the Pan American Health Organization, ${ }^{\mathrm{a}}$ infant mortality rate (IMR) estimates of deaths per thousand live births (LB) for children under the age of one for Mexico, Brazil, and Chile in 2011 was 14.1, 16.2, and 7.4, respectively. In 2010, the IMR for the United States, Spain, and Sweden was 6.1, 3.2, and 2.5 deaths per thousand LB, respectively. ${ }^{b}$
Infant mortality is uneven throughout Brazilian regions. ${ }^{21}$ The average IMR in Brazil in 2010 was $16.0 / 1,000 \mathrm{LB}$ and the highest rates were found in the North (21.0/1,000 LB), Northeast (19.1 per thousand LB), and in the Midwest (15.9 per thousand LB) region. Sergipe (SE), Northeastern Brazil, presented an IMR of 18.2 deaths per thousand LB. ${ }^{\mathrm{c}}$ The urban environment wherein the child lives is considered to be a social determinant of the child's health. The risk of death to which the child will be submitted during the first year of life is associated with the demographic and socioeconomic indicators of where he/she lives, such as urbanization, access to sanitation and housing, income level, and mother's level of education. ${ }^{20}$ Therefore, indicators composed of social variables are created to estimate the living conditions of the population ${ }^{5,20}$ and to contribute to creating monitoring areas of social injustices. ${ }^{17}$

The objective of this study was to analyze the variation in infant mortality per living conditions.

\footnotetext{
a Organização Pan-Americana da Saúde. Saúde nas Américas: edição de 2012. Panorama regional e perfis de países. Washington (DC); 2012. ${ }^{\text {b } O r g a n i z a t i o n ~ f o r ~ E c o n o m i c ~ C o o p e r a t i o n ~ a n d ~ D e v e l o p m e n t . ~ I n f a n t ~ M o r t a l i t y . ~ H e a l t h . ~ P a r i s ; ~ 2012 . ~(K e y ~ T a b l e s ~ f r o m ~ O E C D, ~ 9) . ~}$ c Ministério da Saúde. DATASUS. Informações de Saúde: Tabnet. Brasília (DF); 2013 [cited 2013 Jun 27]. Available from: http://www2.datasus. gov.br/DATASUS/index.php?area=02
} 


\section{METHODS}

Ecological population study based on the analysis of secondary data regarding deaths of children under the age of one (without differentiation between neonatal and post-neonatal components) living in Aracaju, SE, from 2001 to 2010. The period was divided into two five-year periods (2001-2005 and 2006-2010) to analyze the variation of infant deaths per indicator of living condition.

Aracaju, the capital of Sergipe, has 39 neighborhoods and an area of $181.8 \mathrm{~km}^{2}$. In 2010 , the city presented a Human Development Index (HDI) of 0.770, an urbanization rate of $100 \%$, a population of 571,149 inhabitants, ${ }^{\mathrm{d}}$ and a total of $9,311 \mathrm{LB} .{ }^{\mathrm{c}}$

Data from the Sistema de Informação de Mortalidade (SIM - Mortality Information System) and from the Sistema de Informação de Nascidos Vivos (SINASC - Live Births Information System) from Aracaju were used for the calculation of IMR. The IMR was calculated in a direct way, given that Aracaju had an overall mortality rate greater than 5.3 and a percentage of ill-defined causes below $2.0 \%$ over the study period (97.5\% for 2001-2005 and 97.8\% for 2006-2010). ${ }^{6,19}$

The general IMR was calculated by dividing the number of deaths of children under the age of one by the total number of LB for every thousand LB. ${ }^{19}$ The specific IMR was calculated for each basic cause of death. The determination of the basic cause of death followed the recommendations of the International Statistical Classification of Diseases and Related Health Problems (ICD-10). The causes were grouped in accordance with a reduced list of compiled causes of infant death: perinatal problems (ICD-10: P00-P96), acute respiratory infections (ICD-10: J00-J39), diarrheal diseases (ICD-10: A00- A09), other infectious and parasitic diseases (ICD-10: A15-B99), congenital malformations (ICD-10: Q00-Q99), neoplasms (ICD-10: C00-C97), external causes (ICD-10: V01-Y98), and other causes (other codes ICD-10).

The elaboration of the Living Conditions Index (LCI) for each neighborhood was performed based on the demographic data from the 2010 census of the Brazilian Institute of Geography and Statistics (IBGE), ${ }^{\mathrm{d}}$ by means of adapting the methodology described by Costa et $\mathrm{al}^{5}$ (2001), who used five indicators related to the proxy variables of living conditions. Two of the indicators were excluded for not having statistically significant differences between the neighborhoods: average number of residents per household and percentage of households connected to the water supply network. Three indicators were used representing education, income, and housing: proportion of illiterate people who were heads of households; proportion of households earning less than $1 / 4$ of the minimum wage per capita; and proportion of households in subnormal clusters.

The LCI was established for each neighborhood, based on the aforementioned indicators. The organization of scores enabled the grouping of each district into four strata (quartiles), comprising relatively homogeneous areas of living conditions according to the final score: "high" (3-24), "intermediate" (25-44), "low" (45-60), and "very low" (62-90). This stratification was chosen to maintain the balance among the divisions as each stratum was composed of $25.0 \%$ of the observations. The first three strata were composed of ten neighborhoods and the last one was composed of nine. The LCI was spatially distributed on the thematic map by means of the ArcGIS software (Figure 1), which makes the creation and the modeling of maps possible.

The Student's t-test with $\mathrm{p}<0.05$ significance level was used to compare the average rates of infant mortality and specific mortality during both periods.

This study was approved by the Ethics and Research Committee of Universidade Tiradentes (Protocol 060 711) and complied with all the recommendations of Resolution 466/2012 of the National Commission on Research Ethics.

\section{RESULTS}

The IMR decreased from 29.5 in 2001 to 17.7 deaths per thousand LB in 2010 (Figure 2). The average IMR decreased in all the living condition strata between the two five-year periods. The strata "very low" and "high" were the ones with the highest reduction percentages $(34.7 \%$ and $33.8 \%$, respectively). Average infant mortality rates differed between the two periods in all the living condition strata, except for the "intermediate" strata (Table 1).

The main causes of death in 2001-2005 were perinatal problems, with an average IMR of 18.1 deaths per thousand LB, which significantly reduced during 2006-2010 to 12.3. Deaths from diarrheal causes and from other infectious and parasitic diseases have ceased to exist in the "high" strata. This did not occur in the other strata, despite the significant reduction (Table 3).

Deaths from diarrheal diseases showed the greatest reduction $(-84.8 \%)$. The causes of infant mortality due to congenital malformations and external causes presented an increase over the study period (Table 2).

\section{DISCUSSION}

IMR decreased significantly between the two five-year periods in Aracaju. This decrease has been associated

\footnotetext{
d Instituto Brasileiro de Geografia e Estatística. SIDRA Sistema IBGE de Recuperação Automática. Censo Demográfico e Contagem da População. Brasília (DF); 2010. Available from: http://www.sidra.ibge.gov.br/cd/cd2010RgaAdAgsn.asp
} 


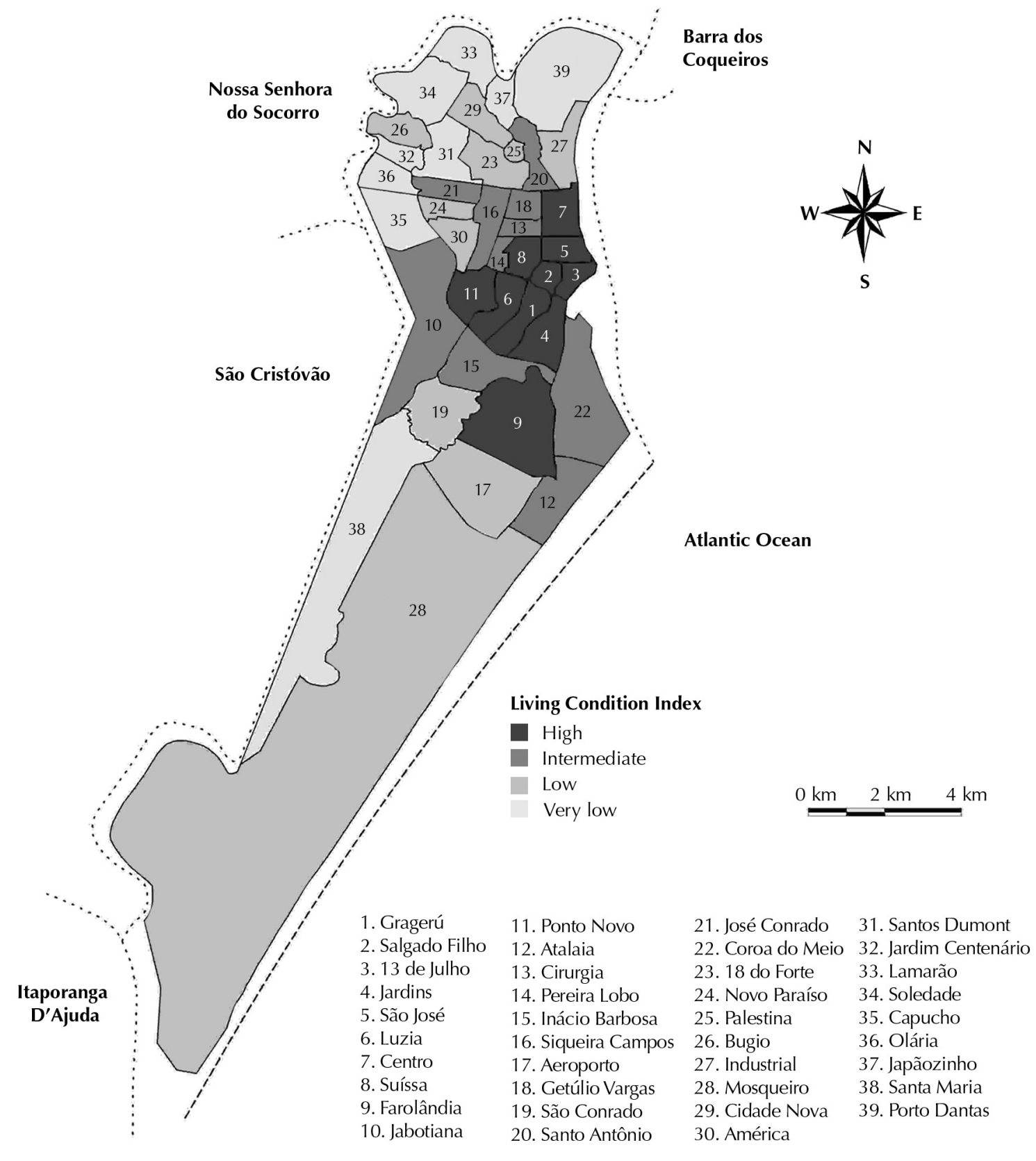

Figure 1. Spatial distribution of the Living Conditions Index according to strata in neighborhoods. Aracaju, SE, Northeastern Brazil, 2001 to 2010.

to improvements in access to prenatal care, ${ }^{21}$ water supply, ${ }^{18}$ sanitation, and an increase of public expenditure on health in Brazil. ${ }^{22}$

The expansion of the Primary Health Care (PHC) in Brazil ${ }^{10,21}$ enables greater access to basic health services by the population, which is important for prenatal, delivery and postpartum care, as well as child care after discharge from the hospital. The Estratégia de Saúde da Família (Family Health Strategy) had an important role in reducing child mortality in Brazilian municipalities from 1996 to $2004 .{ }^{4}$ The program's coverage in Aracaju went from $61.8 \%$ in 2002 to $84.8 \%$ in 2010 . $^{\text {T }}$ The same occurred in Sao Paulo, where the decrease in infant mortality was influenced by the growth of GDP per capita and by the coverage provided by the Equipes de Saúde da Família (Family Health Teams) between 1998 and $2008 .{ }^{10}$ The

e Ministério da Saúde. Departamento de Atenção Básica. Brasília (DF); 2013 [citado 2013 Jun 27]. Available from: http://dab.saude.gov.br/ portaldab/historico_cobertura_sf.php 


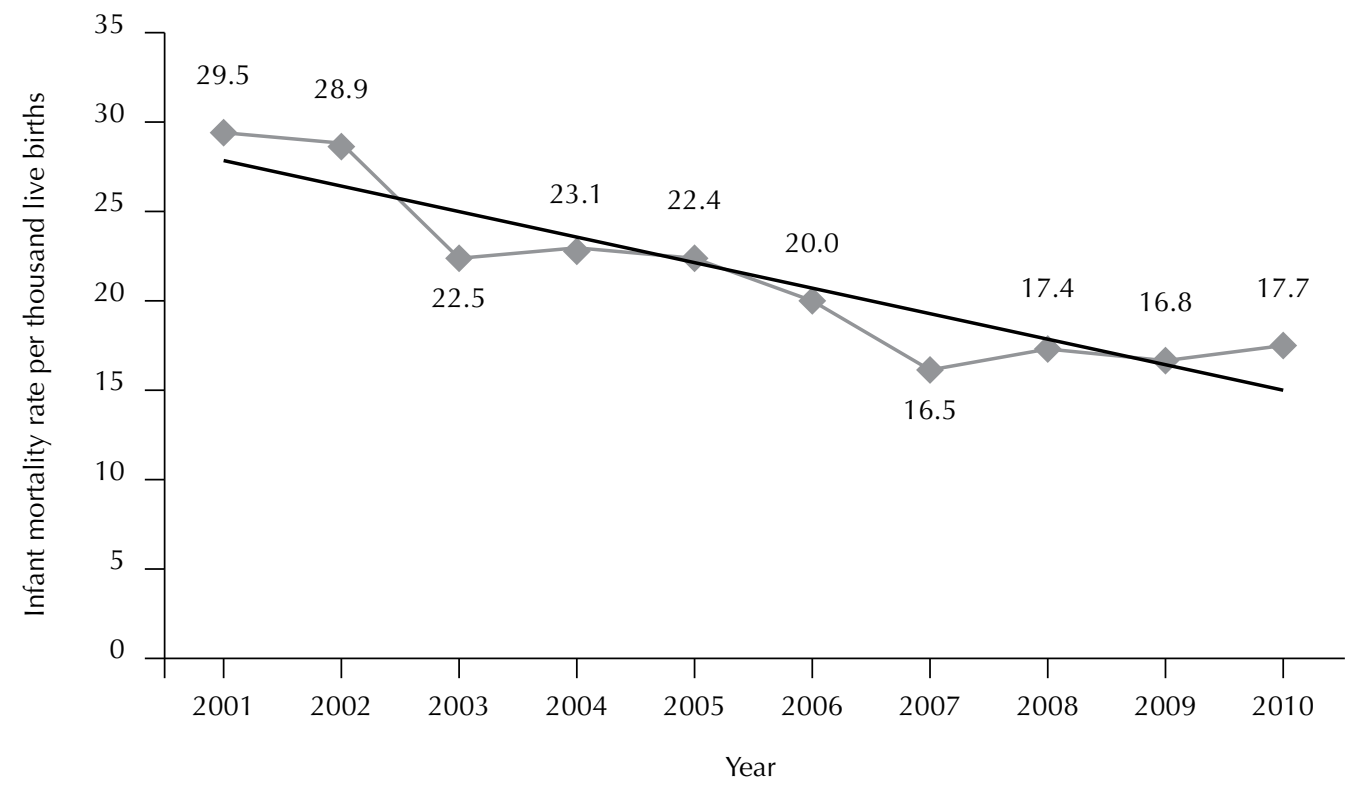

Figure 2. Infant mortality per thousand live births. Aracaju, SE, Northeastern Brazil, 2001 to 2010.

reorganization of the $\mathrm{PHC}$ in Colombia was associated to a reduction of $19.0 \%$ of IMR between 2003 and 2007, primarily of deaths associated to socioeconomic inequalities and housing. ${ }^{13}$

The "high" strata showed lower average rates in comparison to other strata in the two periods, in the comparisons of the average and specific IMR. This indicates inequalities in the occurrences of infant death between the strata, accentuated from 2006 to 2010, when the risk increased in the "intermediate," "low," and "very low" strata in comparison to the previous period. Despite the slowing down of IMR in all the strata during that decade, inequality with regards to infant mortality increased in the areas with the worst living conditions in comparison to areas with better conditions. Maia et $\mathrm{al}^{11}$ (2012) pointed to extreme inequalities in the profile of infant mortality in five Brazilian municipalities of different regions. The inequalities were strongly associated with socioeconomic conditions and access to health services, becoming an indicator of lack of equality. The chances of death in children under the age of one, were also higher among children from disadvantaged social classes in the United Kingdom from 1994 to $2011 .^{23}$

In Belgium, from 1999 to 2008, 85.0\% of deaths in children under the age of one occurred during the first month of life (neonatal deaths), especially during the first week, mainly due to perinatal problems related to prematurity..$^{15}$ In Aracaju, from 2001 to 2010, nearly $77.0 \%$ of deaths occurred in the first month of life, and perinatal problems accounted for $70 \%$ of all infant deaths, rendering it the main cause of death.
The reduction in $32.0 \%$ of deaths due to perinatal causes, from 2006 to 2010, suggests an improvement in prenatal access and hospital care, especially in neonatal intensive care units. ${ }^{3,11,22}$

Congenital malformation was the second cause of death, accounting for about $13.0 \%$ of all deaths and the specific rate remained stable, with variations among strata. The average IMR for this cause in the "intermediate" stratum went from 3.3 deaths per thousand LB in 2001-2005 to 4.3 in 2006-2010. Other Latin American studies showed percentage variations in the occurrence of congenital malformations between $2.0 \%$ and 5.0\%. ${ }^{1,3,7}$ Despite these deaths being difficult to prevent, improvements in family planning and in prenatal care can contribute towards reducing them, since many anomalies are linked to environmental and nutritional factors related to the mother, such as the central nervous system. ${ }^{3}$ Other studies to determine the causes would be required.

The average IMR due to diarrheal diseases from 2001 to 2005 is a strong indicator of inequality in health, greater in the "low" and "very low" strata. Moreover, the occurrence of this cause of death was sporadic from 2006 to 2010 . The decrease of the rate per diarrheal causes was the greatest among all causes and may be associated to improvements in sanitation and greater access to health services..$^{14}$ Furthermore, the provision of the rotavirus vaccine as of 2006 proved to be efficient in reducing child mortality from acute diarrhea. ${ }^{8,9}$ 
Table 1. Average infant mortality rate per thousand live births. Aracaju, SE, Northeastern Brazil, 2001 to 2005 and 2006 to 2010.

\begin{tabular}{lcccc}
\hline \multirow{2}{*}{ Living Condition Index } & \multicolumn{2}{c}{ Average infant mortality rate } & \multirow{2}{*}{$\mathrm{p}^{*}$} \\
\cline { 2 - 3 } High & $2001-2005$ & $2006-2010$ & 0.020 \\
Intermediate & 20.7 & 13.7 & 0.100 \\
Low & 23.1 & 18.4 & 18.0 & 0.009 \\
Very low & 25.4 & 19.6 & $<.001$ \\
Aracaju, SE & 30 & 17.7 & 0.002 \\
\hline
\end{tabular}

* Student $t$ test

Table 2. Specific average of mortality rate per 1,000 live births. Aracaju, SE, Northeastern Brazil, 2001 to 2005 and 2006 to 2010.

\begin{tabular}{lccc}
\hline Causes of death & $2001-2005$ & $2006-2010$ & Difference (\%) \\
\hline Perinatal problems (ICD-10: P00-P96) & 18.11 & 12.30 & -32.1 \\
Acute respiratory infections (ICD-10: J00-J39) & 0.77 & 0.53 & -31.2 \\
Diarrheal diseases (ICD-10: A00- A09) & 0.99 & 0.15 & -84.8 \\
Other infectious and parasitic diseases (ICD-10: A15-B99) & 0.45 & 0.37 & -17.8 \\
Congenital malformations (ICD-10: Q00-Q99) & 2.77 & 2.85 & +2.9 \\
Neoplasms (ICD-10: C00-C97) & 0.02 & 0.02 & 0 \\
External causes (ICD-10: V01-Y98) & 0.26 & 0.32 & +23.1 \\
Other causes (other codes ICD-10) & 1.42 & 0.89 & -37.3 \\
\hline
\end{tabular}

ICD-10: tenth revision of the International Classification of Diseases

The decrease suggests that most neighborhoods experienced improvements in sanitation and access to health services from 2006 to 2010, especially those classified as having "low" and "very low" LCI. Nevertheless, despite the ample reduction, especially in the "high" stratum, the other strata showed deaths due to diarrhea, indicating that they possess important differences in health conditions in comparison to those with better living conditions.

There was a reduction in deaths due to respiratory causes, represented mainly by pneumonia, which like the diarrhea, is treatable through primary care. ${ }^{16}$ The decrease in IMR from respiratory causes probably occurred due to improved access to health services, proper management of cases, and the use, within the public health system, of vaccine against Haemophilus influenzae, an important causative agent of pneumonia in this age range. ${ }^{2}$

The increase of deaths in children under the age of one due to external causes, ${ }^{2}$ especially in the "low" and "very low" LCI neighborhoods, indicates the issue of accidents and violence in this stratum of living conditions, showing the social and health inequalities to which the population is subject. ${ }^{17}$ In the municipality of Cuiabá, upon studying infant deaths due to external causes, it was noted that the more children in a family, the lower was the educational level, and that the lower the mother's age, the greater were the difficulties in preventing accidents within this age group. ${ }^{12}$

Given that this study was based on averages of social and demographic variables and on IMR itself, some limitations are inherent to this type of research. Local differences within the same neighborhood could become masked in the average, thus rendering them impossible to be made evident. However, despite it being a study using aggregated data, it is nonetheless extremely important for the assessment and planning of health care. The "low" and "very low" strata had the worst average rates, except for the analysis of congenital malformations, confirming that, despite progress, health inequalities persist in neighborhoods with the worst living conditions.

Infant mortality rates in Aracaju are decreasing, but they show important differences between neighborhoods. The research from the perspective of living conditions shows the differences in infant mortality within urban areas. We are not attempting to list definite associations, but are in fact attempting to ratify health inequalities in 


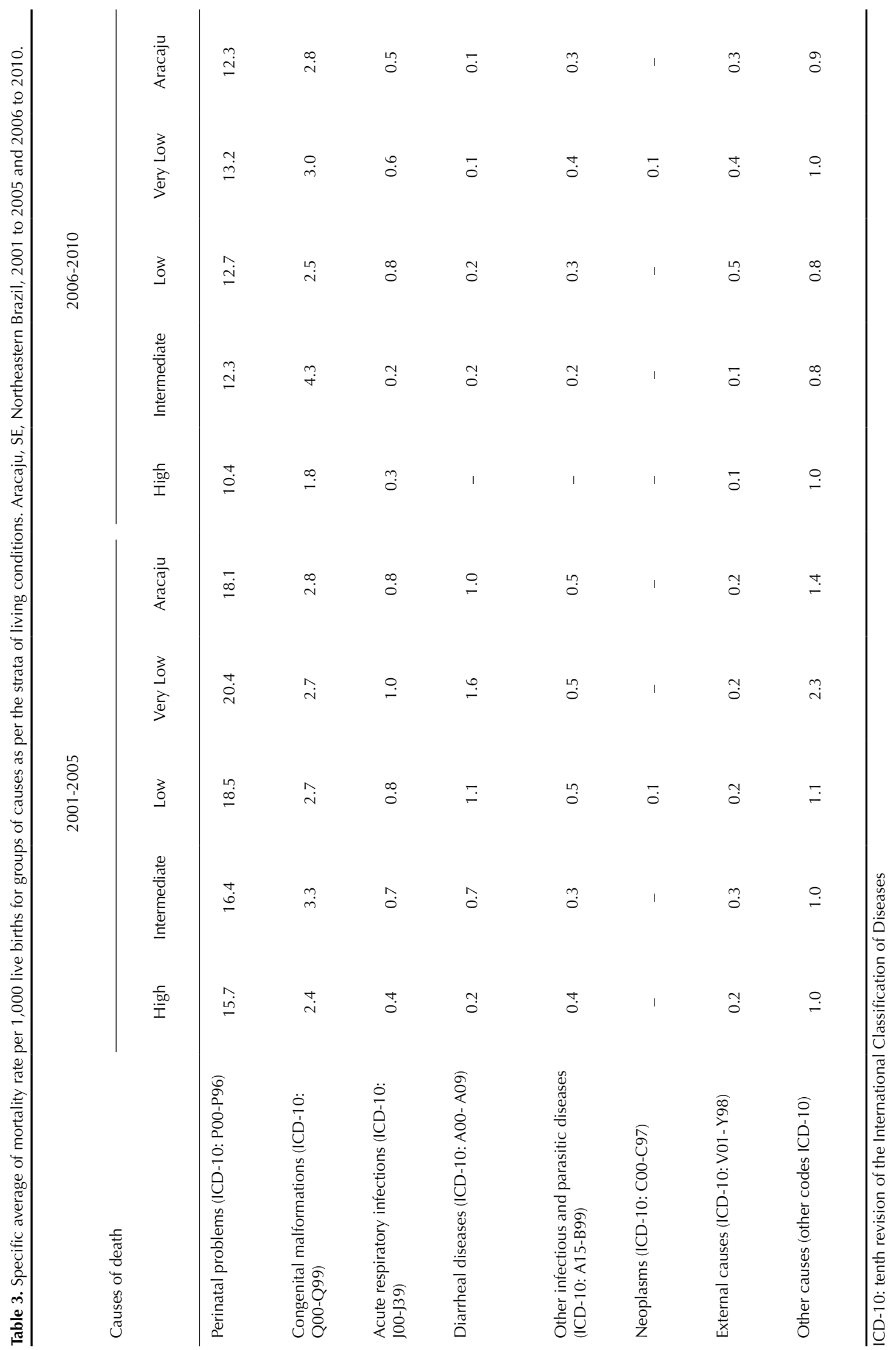


infant mortality as a multidimensional phenomenon that cannot be analyzed from a single perspective.

Despite the significant decrease in infant mortality in Aracaju, it still constitutes a serious problem in certain neighborhoods of the city. The actions of child health policies should consider the urban location, the characteristics of the locales and, social indicators to attain a more accurate estimate of the possible applicability of the resources available.

\section{REFERENCES}

1. Aguila A, Nazer J, Cifuentes L, Mella P, de la Barra P, Gutiérrez D. Prevalencia de malformaciones congénitas al nacer y factores asociados en Isla de Pascua, Chile (1988-1998). Rev Med Chile. 2000;128(2):162-6. DOI:10.4067/S0034-98872000000200005

2. Alves AC, França E, Mendonça ML, Rezende EM, Ishitani LH, Côrtes M CJW. Principais causas de óbitos infantis pós-neonatais em Belo Horizonte, Minas Gerais, Brasil, 1996 a 2004. Rev Bras Saude Matern Infant. 2008;8(1):27-33. DOI:10.1590/S1519-38292008000100004

3. Amorim MMR, Vilela PC, Santos ARVD, Lima ALM $\mathrm{V}$, Melo EFP, Bernardes HF, et al. Impacto das malformações congênitas na mortalidade perinatal e neonatal em uma maternidade-escola do Recife. Rev Bras Saude Matern Infant. 2006;6(Suppl 1):19-25. DOI:10.1590/S1519-38292006000500003

4. Aquino R, Oliveira NF, Barreto ML. Impact of the Family Health Program on Infant Mortality in Brazilian Municipalities. Am J Public Health. 2009;99(1):87-93. DOI:10.2105/AJPH.2007.127480

5. Costa MC, Azi PA, Paim JS, Silva LM. Infant mortality and living conditions: the reproduction of social inequalities in health during the 1990s. Cad Saude Publica. 2001;17(3):555-67. DOI:10.1590/S0102-311X2001000300011

6. Frias PG, Szwarcwald CL, Lira PIC. Estimação da mortalidade infantil no contexto de descentralização do sistema único de saúde (SUS). Rev Bras Saude Matern Infant. 2011;11(4):463-70. DOI:10.1590/S1519-38292011000400013

7. García H, Salguero GA, Moreno J, Arteaga C, Giraldo A. Frecuencia de anomalías congénitas en el Instituto Materno Infantil de Bogotá. Biomedica. 2003;23(2):161-72. DOI:10.7705/biomedica.v23i2.1208

8. Gurgel RG, Bohland AK, Vieira SCF, Oliveira DMP, Fontes PB, Barros VF, et al. Incidence of rotavirus and all-cause diarrhea in northeast Brazil following the introduction of a national vaccination program. Gastroenterology. 2009;137(6):1970-5. DOI:10.1053/j.gastro.2009.07.046

9. Gurgel RQ, Ilozue C, Correia JB, Centenari C, Oliveira SMT, Cuevas LE. Impact of rotavirus vaccination on diarrhoea mortality and hospital admissions in

\section{ACKNOWLEDGEMENTS}

To the Secretaria de Planejamento of the city of Aracaju through its GIS department, for providing the thematic map of the city, whereby it was possible to spatially distribute the Living Conditions Index.

To the Secretaria Municipal da Saúde of Aracaju for providing access to the local databases for vital statistics (SIM and SINASC).

Brazil. Trop Med Int Health. 2011;16(9):1180-4. DOI:10.1111/j.1365-3156.2011.02844.x

10. Lourenço EDC, Guerra LM, Tuon RA, Vidal e Silva SMC, Ambrosano GMB, Corrente JE, et al. Variáveis de impacto na queda da mortalidade infantil no Estado de São Paulo, Brasil, no período de 1998 a 2008. Cienc Saude Coletiva. 2014;19(7):2055-62. DOI:10.1590/1413-81232014197.18822013

11. Maia LTS, Souza WV, Mendes ACG. Differences in risk factors for infant mortality in five Brazilian cities: a case-control study based on the Mortality Information System and Information System on Live Births. Cad Saude Publica. 2012;28(11):2163-76. DOI:10.1590/S0102-311X2012001100016

12. Matos KF, Martins CBDG. Perfil epidemiológico da mortalidade por causas externas em crianças, adolescentes e jovens na capital do Estado de Mato Grosso, Brasil, 2009. Epidemiol Serv Saude. 2012;21(1):43-53. DOI:10.5123/S1679-49742012000100005

13. Mosquera PA, Hernández J, Vega R, Martínez J, Labonte R, Sanders D, et al. The impact of primary healthcare in reducing inequalities in child health outcomes, Bogotá-Colombia: an ecological analysis. Int J Equity Health. 2012;11:66. DOI:10.1186/1475-9276-11-66

14. Oliveira TCR, Latorre MRDO. Tendências da internação e da mortalidade infantil por diarréia: Brasil, 1995 a 2005. Rev Saude Publica. 2010;44(1):102-11. DOI:10.1590/S0034-89102010000100011

15. Pelfrene $\mathrm{E}, \mathrm{Cloots} \mathrm{H}$, Hendrickx E. Infant mortality in the Flemish Region of Belgium 1999-2008: a timeto-event analysis. Arch Public Health. 2012;70(1):6. DOI:10.1186/0778-7367-70-6

16. Santos HG, Andrade SM, Birolim MM, Carvalho WO, Silva AMR. Mortalidade infantil no Brasil: uma revisão de literatura antes e após a implantação do Sistema Único de Saúde. Pediatr (São Paulo). 2010;32(2):131-43.

17. Silva JB, Barros MBA. Epidemiology and inequality: notes on theory and history. Rev Panam Salud Publica. 2002;12(6):375-83. DOI:10.1590/S1020-49892002001200003

18. Sousa TRV, Leite Filho PAM. Panel data analysis of health status in Northeast Brazil. Rev Saude Publica. 2008;42(5):796-804. DOI:/10.1590/S0034-89102008005000047 
19. Szwarcwald CL, Leal MC, Andrade CLT, Souza PRB. Infant mortality estimation in Brazil: what do Ministry of Health data on deaths and live births say? Cad Saude Publica. 2002;18(6):1725-36. DOI:10.1590/S0102-311X2002000600027

20. Ventura RN, Oliveira EM, Silva EMK, Silva NN, Puccini RF. Condições de vida e mortalidade infantil no município do Embu, São Paulo. Rev Paul Pediatr. 2008;26(3):251-7. DOI:10.1590/S0103-05822008000300009

21. Victora CG, Aquino EML, Leal MC, Monteiro CA, Barros FC, Szwarcwald CL. Maternal and child health in Brazil: progress and challenges. Lancet. 2011;377(9780):1863-76. DOI:10.1016/S0140-6736(11)60138-4

22. Volpe FM, Abrantes MM, Capanema FD, Chaves JG. The impact of changing health indicators on infant mortality rates in Brazil, 2000 and 2005. Rev Panam Salud Publica. 2009;26(6):478-84. DOI:10.1590/S1020-49892009001200002

23. Weightman AL, Morgan HE, Shepherd MA, Kitcher $H$, Roberts C, Dunstan FD. Social inequality and infant health in the UK: systematic review and meta-analyses. BMJ Open. 2012;2(3):e000964. DOI:10.1136/bmjopen-2012-000964

Research supported by the Coordenação de Aperfeiçoamento de Pessoal de Nível Superior (CAPES - Financial Aid - AUXPE-PROSUP 2203/2010, Process 23038009763/201).

Based on the master's thesis of Carvalho RAS, titled: "Avaliação das desigualdades na mortalidade infantil e assistência pré-natal em Aracaju/SE/Brasil", presented to the Programa de Pós-Graduação em Saúde e Ambiente of the Universidade Tiradentes, in 2013.

The authors declare no conflict of interest. 